International Journal of Agriculture, Environment and Bioresearch

Vol. 4, No. 06; 2019

ISSN: $2456-8643$

\title{
INFLUENCE OF LOCAL COAL ON THE AGROCHEMICAL PROPERTIES OF MEAD SOIL AND CROP YIELD
}

\author{
* Uraimov T., Oripov G., Associate professors and Turdieva M. E - Assistant \\ Andijan branch of Tashkent State Agrarian University of the Republic of Uzbekistan
}

http://doi.org/10.35410/IJAEB.2019.4474

\begin{abstract}
Under the conditions of irrigated meadow soils, the influence of the brown coal product on the agrochemical properties of the soil is studied. It has been established that this non-traditional product positively affects the humus content in the soil, thereby contributing to an increase in cotton yield by 2.5-4.1 centners per hectare.
\end{abstract}

Keywords: Brown coal, soil, agrochemical properties, nutrients, cotton, fertility productivity, agriculture.

\section{INTRODUCTION}

In modern conditions of the development of human society, technogenic and anthropogenic impacts on the environment have become increasingly significant and global. It is known that clean water, air and soil, high-quality food products are decisive factors in human health and human society as a whole [1,2].

It is impossible to stop the progress of mankind, but combining the interests of producers of material goods with a careful attitude to the human environment, ensuring the sustainable development of society, is an urgent task. Environmental issues are particularly acute in the field of agricultural production in connection with the use of intensive technologies using a large number of chemicals.

The soil cover is changing, both as a result of direct targeted human exposure to the soil, and as a result of diverse global, often unforeseen environmental effects. Currently, the annual irretrievable losses of productive land in the world amount to more than 5-6 million hectares, and the problem of combating soil loss is one of the first places among all the environmental problems of the world Therefore, representatives of soil, agrochemical and agricultural sciences should actively contribute to the protection and enhancement of its productive capacity.

The soil is a very peculiar natural biocos body. If rationally used, taking into account the peculiarities of the processes occurring in it, then it can maintain and enhance its fertility for a long time. Moreover, a person with his scientifically based activities can significantly improve the properties of the soil, as well as increase its potential fertility. 
The last fifty years, man-made impacts on the soil cover have intensified. A comparison of different processes shows that salinization, erosion, soil pollution and others, leading to their degradation, are dangerous for our republic.

In our republic and in many foreign countries, the amount of mineral fertilizers applied per hectare of arable land reaches $450-600 \mathrm{~kg}$ of active substance.

The use of high doses of mineral fertilizers and plant protection products, land reclamation of irrigated lands and other factors ensured an increase in the productivity of irrigated arable land in Uzbekistan. Therefore, intensive crop cultivation technologies will remain the main factors in yield growth.

It should be noted that the use of nutrients (nitrogen, phosphorus and potassium) for cultivated plants from mineral fertilizers ranges from 20 to $60 \%$, depending on growing conditions. A significant amount of nutrients enters the environment, accumulates in soil, groundwater, as well as in agricultural products themselves. Of particular concern are the salts of heavy metals that make up mineral fertilizers. According to scientists, in one ton of mineral fertilizers the amount of zinc is 77 , copper 59, chromium 33, nickel 30 and lead 26 grams $[3,4,5]$.

In connection with the above, at present one of the most important issues of the state agrarian policy is the following problems:

- The problem of conservation, protection and reproduction of soil fertility;

- Rational use of land resources in various soil and climatic zones of the republic, without violating the ecological balance of the environment.

In conditions of intensive chemicalization of agriculture, doubts arise about the safety of food products and the anxiety about the threat to humans and animals of the use of high doses of mineral fertilizers and, especially, pesticides, is growing. At present, there are no natural systems for their neutralization and destruction because they are created by chemical synthesis.

Recent studies by the Research Institute of Soil Science and Agricultural Chemistry of the Republic of Uzbekistan have revealed a significant decrease in organic matter in soils. Humus reduction in in soils is naturally accompanied by a decrease in the most valuable agrochemical and agrophysical properties of the soil. In addition, there is a decrease in the content of the main nutrients of cultivated plants (nitrogen, phosphorus, and potassium) in irrigated soils as a result of insufficient implementation of scientifically based technologies for the use of organic and mineral fertilizers and an increase in the cost of basic mineral fertilizers.

Thus, based on the foregoing, there are a number of problems that agrochemists and agronomists of the republic should solve in the coming years.

To solve the above problems and to study an alternative remedy in the irrigated meadow soils of the training and experimental farm of the Andijan branch of the Tashkent State Agrarian University and the Fazliddin Umidli Yerlari farm, field and production experiments were carried out in typical gray soils to determine the effect of the brown coal product on the cotton plant. 
Mineral fertilizers were applied at the following dates: nitrogen- $10 \%$ with sowing, $25 \%$ in the phase of 3-4 true leaves, $35 \%$ in budding and $30 \%$ at the beginning of flowering of cotton. Phosphorus- $65 \%$ in the fall before plowing, $15 \%$ sowing and $20 \%$ at the beginning of flowering. The annual rate of potassium was introduced before plowing, while for the main fertilizer application, an overhead NRU-0.5 was used.

The entire norm of brown coal (2500 and $5000 \mathrm{~kg} / \mathrm{ha}$ ) was introduced for spring tillage. After making a manual method, chiseling was carried out to a depth of $15-20 \mathrm{~cm}$.

Currently, in the Republic of Uzbekistan, the primary task is to solve the problem of soil fertility. Because, during the years of independence of the Republic, the number of cattle sharply decreased, as a result of which the amount of applied organic fertilizers (manure) decreased.

In recent years, studies by many authors have noted a decrease in the yield of our priceless irrigated soils, which are used as the main means of production in agriculture [7.8.9.10].

Instead of a grass-field system of agriculture, an intensive system of alternation was adopted, sowing cotton, sowing, and winter wheat. In this regard, year after year, the agrochemical properties of the soil deteriorate, and crop yields decrease.

To solve this problem, research robots are carried out using various substances that improve soil fertility. One of these substances is the product of brown coal.

Under the conditions of irrigated meadow soils, the influence of the brown coal product on the agrochemical properties of soils and cotton yield is studied. It is established that the product of brown coal contributes to an increase in cotton yield by 2.5-4.1 centners per hectare.

Based on the above, the study of the effect of brown coal on the agrochemical properties of soils is relevant.

As noted above, field experiments were conducted on the fields of the training and experimental farm of the Andijan branch of the Tashkent State Agrarian University. Type of soil irrigated meadow, medium-loam mineralogical composition. Mirror groundwater is at a depth of 1.5-2.0 $\mathrm{m}$, not mineralized.

The purpose of this research was to study the effect of brown coal on certain agrochemical properties of the soil, as well as on the growth, development and productivity of cotton.

The experiments were carried out in 4-fold repetition, consisting of 3 options. The area of one plot is equal to $360 \mathrm{~m} 2(50 \mathrm{~m} \times 7.2=360 \mathrm{~m} 2)$.

Experience outline

1. Control + background (No.-150 kg / ha, R-140kg / ha and K-100 kg / ha).

2. Brown angle of $2500 \mathrm{~kg} / \mathrm{ha}+$ background

3. Brown angle of $5000 \mathrm{~kg} / \mathrm{ha}+$ background 
In field studies, all observations, counts and determinations were carried out according to the method of UZNIIKh (2007) "Methodology for conducting field experiments".

In soil samples taken before the laying of field experiments and during the growing season of plants, the following soil analyzes were carried out:

- Humus content - according to the method of I.V. Tyurin.

- Total nitrogen, phosphorus and potassium - according to the method of Maltsev and Gritsenko.

- Nitrate nitrogen (N-NO3) - according to Grandwald - Lyazh.

- Mobile phosphorus (P2O5) - according to I. Machigin.

- Exchange potassium (K2O) - on a flame photometer.

The soils of the experimental farm, as indicated above, irrigated meadow soils. The volumetric mass of the studied soil according to the testimony of field studies is $1.25 \mathrm{~g} / \mathrm{cm} 3$, soil samples were taken at horizons of $0-30,30-50,50-70$ and 70-100 $\mathrm{cm}$ to one meter.

Based on the results of the chemical analysis of the samples (Table 1), it can be said that the physical, agrochemical properties of the soils of the experimental plot correspond to the irrigated meadow soils of the Andijan region.

Table 1 Agrochemical properties of the soil before laying the field experience

\begin{tabular}{|c|c|c|c|c|c|c|c|c|}
\hline \multirow{2}{*}{$№$} & \multirow{2}{*}{$\begin{array}{c}\text { Depth of } \\
\text { horizon cm }\end{array}$} & \multirow{2}{*}{$\begin{array}{c}\text { Gumus, } \\
\% \ldots\end{array}$} & \multicolumn{2}{|c|}{ The content of gross nutrients, $\%$} & \multicolumn{3}{c|}{ Mobile forms of nutrients, $\mathrm{mg} / \mathrm{kg}$} \\
\cline { 4 - 9 } & & & nitrogen & phosphorus & potassium & $\mathrm{N}^{-\mathrm{NO}_{3}}$ & $\mathrm{P}_{2} \mathrm{O}_{5}$ & $\mathrm{~K}_{2} \mathrm{O}$ \\
\hline 1 & $0-30$ & 1.85 & 0.171 & 0.146 & 1.63 & 21.4 & 31.4 & 205 \\
\hline 2 & $30-50$ & 1.01 & 0.078 & 0.1231 & 1.50 & 9.8 & 23.0 & 190 \\
\hline 3 & $50-70$ & 0.49 & 0.039 & 0.042 & 1.01 & 4.7 & 10.2 & 182 \\
\hline 4 & $70-100$ & 0.23 & 0.013 & 0.021 & 1.01 & 2.1 & 8.1 & 165 \\
\hline
\end{tabular}

The obtained laboratory analysis results show that in the arable horizon the humus content is $1.85 \%$, in the sub-arable $(30-50 \mathrm{~cm})$ layer $-1.01 \%$ is determined. In the horizon of $70-100 \mathrm{~cm}$, the humus content in the amount of $-0.23 \%$.

The content of gross nitrogen in the arable $(0-30 \mathrm{~cm})$ horizon is $0.171 \%$. In the lower horizons of the soil, the content of gross nitrogen decreases significantly. The minimum amount of gross nitrogen is $-0.013 \%$. The same pattern is observed in the total phosphorus content, but the following are revealed in the potassium content: the maximum amount of total potassium in the soil is found in the arable $(0-30 \mathrm{~cm})$ horizon $-1.63 \%$, the minimum amount of potassium $-1.01 \%$ defined in the horizons of $50-70$ and $70-100 \mathrm{~cm}$.

The content of mobile forms of nutrients is as follows: 
Nitrate nitrogen in the arable horizon was determined to be $21.4 \mathrm{mg} / \mathrm{kg}$, phosphorus - 31.4 and exchange potassium in an amount of $-205 \mathrm{mg} / \mathrm{kg}$.

Thus, the content of mobile nutrients in the soil: nitrate nitrogen, corresponds to a low-income group. And in terms of the content of exchange potassium and mobile phosphorus (P2O5; K2O), it corresponds to the average secured group of soils; their content in the arable layer is 31.4 and $205 \mathrm{mg} / \mathrm{kg}$, respectively.

In the experiment, mineral fertilizers were used according to accepted recommendations for this region. All agrotechnical measures for the cultivation of cotton were also carried out efficiently and in optimal time.

\section{RESEARCH RESULTS}

Creating a deficit-free balance of humus in the soil is the most important task of crop rotation. The use of organic fertilizers also contributes to an increase in humus and nutrients. In this regard, the results of the influence of the brown coal product introduced under cotton on the humus content and soil nutrients were studied. Based on this, certain research results were obtained (table 2).

Table 2 The effect of brown coal product on the content of humus and mobile soil elements

\begin{tabular}{|c|c|c|c|c|c|c|c|c|c|c|}
\hline \multirow[b]{2}{*}{ № } & \multirow{2}{*}{ Experience Options } & \multirow{2}{*}{$\begin{array}{c}\text { Depth of } \\
\text { horizon } \\
\mathrm{cm}\end{array}$} & \multicolumn{4}{|c|}{$\begin{array}{l}\text { At the beginning of } \\
\text { flowering }\end{array}$} & \multicolumn{4}{|c|}{$\begin{array}{l}\text { At the end of the growing } \\
\text { season }\end{array}$} \\
\hline & & & 竘 & $\begin{array}{l}\hat{O}_{2} \\
\dot{1} \\
\dot{z}\end{array}$ & $\overbrace{0}^{n}$ & $\begin{array}{l}0 \\
\stackrel{\mathscr{\Omega}}{2}\end{array}$ & 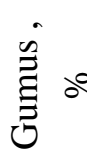 & $\begin{array}{l}0 \\
z \\
z \\
z\end{array}$ & $\overbrace{0}^{n}$ & $\begin{array}{l}0 \\
\stackrel{2}{2}\end{array}$ \\
\hline \multirow{2}{*}{1} & \multirow{2}{*}{$\begin{array}{l}\text { №-150 } \\
\text { P-140+background } \\
\text { K-100 }\end{array}$} & $0-30$ & 1.85 & 20.2 & 30.2 & 205 & 1.48 & 14.3 & 24.2 & 290 \\
\hline & & $30-50$ & 1.23 & 9.6 & 27.8 & 155 & 0.86 & 7.2 & 21.4 & 150 \\
\hline \multirow{2}{*}{2} & \multirow{2}{*}{$\begin{array}{l}\text { Brown corner } 2500 \\
\mathrm{~kg} / \text { ha } \\
+ \text { background }\end{array}$} & $0-30$ & 1.82 & 32.4 & 34.1 & 215 & 1.54 & 17.6 & 25.3 & 205 \\
\hline & & $30-50$ & 1.20 & 11.3 & 26.8 & 165 & 0.91 & 10.5 & 20.6 & 150 \\
\hline \multirow{2}{*}{3} & \multirow{2}{*}{$\begin{array}{l}\text { Brown corner } 5000 \\
\mathrm{~kg} / \text { ha } \\
+ \text { background }\end{array}$} & $0-30$ & 1.84 & 34.1 & 35.9 & 220 & 1.55 & 19.1 & 26.5 & 205 \\
\hline & & $30-50$ & 1.21 & 11.9 & 27.1 & 160 & 0.89 & 10.8 & 20.9 & 145 \\
\hline
\end{tabular}

According to the results of chemical analysis of soils, the humus content at the beginning of the growing season in the arable layer $(0-30 \mathrm{~cm})$, irrigated meadow soils is $1.82-1.85 \%$, in the horizon $30-50 \mathrm{~cm}$, in the control variant the humus content in the arable horizon $(30-50 \mathrm{~cm})$ of soils equals $0.86 \%$. Most of the humus was found in option-3, where $5000 \mathrm{~kg} /$ ha of brown coal product- $1.55 \%$ was added 
The content of mobile phosphorus and exchange potassium has also been established, more on options where a brown coal product was used. $\mathrm{P} 2 \mathrm{O} 5$ in the arable horizon was greater by 3.6 and $5.7 \mathrm{mg} / \mathrm{kg}$

The results of chemical analyzes show in the subsurface horizon $(30-50 \mathrm{~cm})$ of all variants of the field experiment the content of humus, nitrate nitrogen, mobile phosphorus and exchange potassium in the soil is significantly less than in the arable horizon $(0-30 \mathrm{~cm})$

The nitrogen content in nitrate form (N-NO3) at the beginning of the growing season (flowering) of cotton in the control version is $20.2 \mathrm{mg} / \mathrm{kg}$, to the bottom $(30-50 \mathrm{~cm})$ its content sharply decreases to $9.6 \mathrm{mg} / \mathrm{kg}$ of soil weight. Most nitrate nitrogen was determined when using a product of brown coal in the amount of $5000 \mathrm{~kg}$ per hectare (horizon $0-30 \mathrm{~cm}$ ) $34.1 \%$.

At the beginning of the growing season, the content of mobile phosphorus was most determined in samples taken from the 3rd option $-35.9 \mathrm{mg} / \mathrm{kg}$ of soil. There was more exchange potassium as well as $\mathrm{N}$ and $\mathrm{P}$ in the arable $(0-30 \mathrm{~cm})$ horizon of the option where the brown coal product was used at a rate of $5000 \mathrm{~kg} / \mathrm{ha}$, and $220 \mathrm{mg} / \mathrm{kg}$ of soil was established.

At the end of the cotton growing season, the content of humus and mobile elements significantly decreased, which is associated with the assimilation of cotton by plants during the growing season. Humus is least defined in option -1 , where no brown coal product was used (control option) $-1.48 \%$. Most of the humus is found in the -3 variant in the amount of $1.55 \%$. In the content of nitrogen and phosphorus, a pattern is also observed, which is established as in the content of humus.

Under the conditions of irrigated meadow soils, the influence of the brown coal product on the agrochemical properties of soils, as well as on cotton productivity, was studied.

It was established that this non-traditional product positively affects the content of humus, as well as nutrients in the soil, thereby contributing to an increase in cotton productivity by $2.5-4.1$ centners per hectare.

Exchange potassium in the arable horizon $(0-30 \mathrm{~cm})$ of the soil was most contained in the control variant and equals $-290 \mathrm{mg} / \mathrm{kg}$. In the subsurface horizon $(30-50 \mathrm{~cm})$ of all variants of the field experiment, the content of humus, nitrate nitrogen, mobile phosphorus and exchange potassium is significantly lower than in the arable horizon. In our opinion, this is due to the growth of the root system of plants and the assimilation of these nutrients for the growth, development and harvest of raw cotton. Because, cotton plants intensively consume nitrogen and phosphorus from the period of budding to ripening.

Numerous studies have established that cultivated soils can be obtained a high yield only with the targeted regulation of plant nutrition, crop requirements and variety characteristics. The nutrition process of cultivated plants can be controlled by differentiating the forms, doses, timing and methods of applying organic and mineral fertilizers. This pattern must be taken into account in the interactions of environmental factors. 
According to the experiments in different soil-climatic zones of Uzbekistan in optimal cases, due to fertilizers, $40-50 \%$ of the cotton crop is formed. Fertilizers even more strongly affect the consumption of nutrients by plants [6].

In our scientific research on an innovative project, the use of a brown coal product together with mineral fertilizers obtained the following results (table 3).

Table 3 The effect of the brown coal product on the cotton crop

\begin{tabular}{|c|c|c|c|c|c|c|c|}
\hline № & Options & \multicolumn{4}{|c|}{ Repetitions } & $\begin{array}{l}\text { Average } \\
\text { crop ts / ha }\end{array}$ & $\begin{array}{c}\text { Difference } \\
+,- \\
\text { ts } / \text { ha }\end{array}$ \\
\hline 1 & $\begin{array}{l}\text { N-150 } \\
\text { P-140+ background } \\
\text { K-90 }\end{array}$ & 33,5 & 33,1 & 34,2 & 33,4 & 33,6 & 0,0 \\
\hline 2 & $\begin{array}{l}\text { Brown coal } 2500 \\
\mathrm{~kg} / \mathrm{ha} \\
+ \text { background }\end{array}$ & 35,8 & 35,7 & 36,4 & 35,7 & 35,9 & 2,9 \\
\hline 3 & $\begin{array}{l}\text { Brown coal } 5000 \\
\mathrm{~kg} / \text { ha } \\
+ \text { background }\end{array}$ & 37,4 & 38,3 & 37,5 & 37,6 & 37,7 & 4,1 \\
\hline
\end{tabular}

It was established that when using only mineral fertilizers (control option), the yield of raw cotton was $33.6 \mathrm{c} /$ ha. In options 2 and 3, using a brown coal product together with mineral fertilizers at doses of 2500 and $5000 \mathrm{~kg} / \mathrm{ha}$, the yield was 35.9 and 37.7 centners per hectare, respectively. The yield increase in comparison with the control option was 0.29 and $0.41 \mathrm{t} / \mathrm{ha}$, or 10.7 and $11.2 \%$ [11].

Thus, it can be concluded that the use of a brown coal product in conditions of irrigated meadow soils positively affects the growth, development and productivity of cotton.

\section{CONCLUSIONS}

1. The combined use of mineral fertilizers with brown coal products in the norm of 2500 and 500 $\mathrm{kg} / \mathrm{ha}$ in the conditions of irrigated meadow soils positively affects the agrochemical properties.

2. The use of brown coal product in the norm of $5000 \mathrm{~kg} /$ ha contributes to an increase in the yield of raw cotton by 2.5-4.1 centners per hectare.

\section{REFERENCES}

1.Autko A. A. Increasing the environmental safety levels of the production of vegetables and potatoes. The journal "Belarusian Agriculture". 2017, N2 p. 22-25.

2. Borisov V. A. Features of nutrition of vegetable crops and methods for producing environmentally friendly products. J. Potato and Vegetables-2009. No. 8 p.12-14 
3.Litvinov S.S. Vegetables, quality, health. Sat scientific Trudov-M .: FSBI VNIIO; 2014 s. 1420.

4. Tarasenko, S. A. Physiological and agrochemical features of the production process of the main agricultural crops. Monograph. Grodno: 2012-200s

5. Organic farming in Germany. Expert Information (VINITI) -M: 2008-p.23-39.

6. Dovban K.I. Transition from traditional to bioorganic farming in the Republic of Belarus. Minsk: "Belarusian Navuka" 2016. 89 s

7. Zokirov T. Agrochemical basis for the cultivation of cotton. Toshkent: FAN. 1987. $214 \mathrm{p}$.

8. Karimberdieva et al. The influence of unconventional mineral raw materials on the trace element composition of soils. Magazine "Soil Science and Agrochemistry" No. 3. Almaty: 2015.63-68s.

9.Rubenshtein M., Sultanov B. Efficiency of application of nitrogen and phosphorus fertilizers. Ryazan: 2001.297-299 s.

10. Uraimov T. Andijon viloyati tuproқlari wa unumdorliga. Стон Uzbekistan Tupro $к$ Shunoslari VA Agrokimyogarlari Zhamiyating V-Kuriltoyi materiallari. T.: 2010. 162-164 b.,

11. Report on the innovative project І-ҚХ-2017-5-47 "Implementation of the technology for producing brown coal products for agricultural plants and machinery." Andijon: 2017. 